Jurnal THEOREMS (The Original Research of Mathematics) Vol. 5 No. 2, Januari 2021. hal. 221-228

URL: http://jurnal.unma.ac.id/index.php/th

Naskah masuk: 24-12-2020 Naskah diperbaiki: 04-01-2021 Naskah diterima: 05-01-2021

PENERAPAN STRATEGI DRILL DAN TUGAS UNTUK MENINGKATKAN

KEMAMPUAN PEMECAHAN MASALAH

\title{
IMPLEMENTING STRATEGIES OF DRILL AND ASSIGNMENT TO IMPROVING PROBLEM SOLVING ABILITY
}

\author{
Anwar Ardani $1^{*}$, Dian Purwaningsih ${ }^{2}$ \\ 1,2Universitas Peradaban, Jl. Raya Pagojengan Km. 3 Kec. Paguyangan Kab. Brebes \\ email: anwarardani3@gmail.com
}

\begin{abstract}
ABSTRAK
Penelitian ini didasari dari kemampuan mahasiswa yang mana mahasiswa belum bisa merumuskan hipotesis nol dan hipotesis alternatif yang tepat sesuai dengan pertanyaan atau permasalahan yang ditanyakan. Tujuan dari penelitian ini adalah untuk mengetahui ada atau tidaknya peningkatan kemampuan pemecahan masalah mahasiswa dari sebelum diberikan perlakuan strategi drill dan tugas dengan setelah diberikan perlakuan strategi drill dan tugas. Penelitian ini merupakan eksperimental semu dengan desain one group pretest-posttest design. Populasi pada penelitian ini adalah semua mahasiswa Pendidikan Guru Sekolah Dasar yang mengikuti matakuliah statistika pendidikan pada semester ganjil tahun ajaran 2019/2020. Teknik pengambilan sampel pada penelitian ini menggunakan simple random sampling. Penelitian dilakukan kepada 30 mahasiswa PGSD yang mengikuti matakuliah statistika pendidikan. Teknik pengumpulan data menggunakan metode tes. Analisis data pada penelitian menggunakan uji T berpasangan. Hasil penelitian menunjukan bahwa terdapat peningkatan kemampuan pemecahan masalah mahasiswa dari sebelum diberikan perlakuan strategi drill dan tugas dengan setelah diberikan perlakuan strategi pemberian drill dan tugas.
\end{abstract}

Kata kunci: Kemampuan pemecahan masalah, Strategi drill dan tugas

\section{ABSTRACT}

This research is based on the ability of students in which students have not been able to formulate a null hypothesis and an alternative hypothesis that is appropriate to the question or problem being asked. The purpose of this study was to determine whether or not there is an increase in student problem solving abilities from before being given the drill strategy and assignment treatment to after being given the drill strategy and assignment treatment. This research is a quasi-experimental design with one group pretest-posttest design. The population in this study were all elementary school teacher education students who took the education statistics course in the odd semester of the 2019/2020 school year. The sampling technique in this study used simple random sampling. The research was conducted on 30 PGSD students who took educational statistics courses. The data collection technique used the test method. The data analysis in this research used paired $\mathrm{T}$ test. The results showed that there was an increase in students' problem solving abilities from before being given the drill and assignment strategy treatment to after being given the drill and assignment giving strategy treatment

Keywords: The Ability of Problem Solving, Strategies of Drill and 


\section{PENDAHULUAN}

Sebagai calon guru sekolah dasar, mahasiswa PGSD dituntut untuk bisa menguasai lima mata pelajaran pokok yaitu Bahasa Indonesia, Ilmu Pengetahuan Sosial, Ilmu Pengetahuan Alam, Matematika, dan Muatan Lokal. Dari kelima mata pelajaran, matamatika merupakan mata pelajaran yang dianggap paling sulit.

Matematika merupakan mata pelajaran yang diajarkan dari pendidikan dasar hingga pendidikan tinggi termasuk di program studi PGSD. Salah satu mata kuliah matematika yang terdapat dalam kurikulum PGSD adalah statistika pendidikan. Statistika adalah pengetahuan yang berhubungan dengan cara penyusunan data, penyajian data, dan penarikan kesimpulan mengenai suatu keseluruhan (yang disebut populasi) berdasarkan data yang ada pada bagian dari keseluruhan tadi [2]. Dalam matematika, ada lima kompetensi utama berdasarkan pada kemampuan yaitu: pemahaman matematik, pemecahan masalah, komunikasi matematik, koneksi matematik, dan penalaran matematik, kemampuan yang lebih tinggi diantaranya adalah kemampuan berpikir kritis matematik dan kemampuan berpikir kreatif matematik [2]. Pemecahan masalah merupakan suatu proses atau upaya individu untuk merespon atau mengatasi halangan atau kendala ketika suatu jawaban atau metode jawaban yang belum tampak benar [10]. Kemampuan individu atau mahasiswa untuk merespon suatu suatu pertanyan dalam pembelajaran statistika pembelajaran masih belum benar.

Berdasarkan hasil pengamatan pada proses pembelajaran dan hasil ujian matakuliah statistika pendidikan. Mahasiswa memang sudah dapat memahami masalah (apa saja yang diketahui dan apa yang ditanyakan dari soal yang ditanyakan) dari pertanyaan yang dibuat. Akan tetapi, sebagian mahasiswa belum bisa merumuskan hipotesis nol dan hipotesis alternatif. Sebagian mahasiswa masih belum tepat dalam menentukan rumus atau statistika uji yang digunakan dalam uji mengenai rerata. Ada enam rumus dalam uji hipotesis mengenai rerata. Misalnya, berdasarkan soal sudah diketahui bahwa soal tersebut seharusnya menggunakan rumus ke tiga, akan tetapi mahasiswa menggunakan rumus ke empat [2].

Permasalahan tersebut dimungkinkan karena kurangnya mahasiwa dalam mengerjakan latihan soal sehingga mahasiswa kurang merencanakan penyelesaian sesuai dengan pertanyan pada permasalahan. Latihan soal memungkinkan mahasiswa dapat meningkatkan kemampuan pemecahan masalah mahasiswa. Strategi pembelajaran yang membuat mahasiwa menjadi banyak menerjakan latihan soal dan memungkinkan dapat meningkatkan kemampuan pemecahan masalah mahasiswa adalah strategi drill dan tugas.

Strategi drill dan tugas merupakan gabungan dari dua metode belajar yaitu metode pembelajaran drill dan metode pembelajaran pemberian tugas. Metode pembelajaran drill adalah cara mengajar dengan cara malaksanakan latihan supaya peserta didik memiliki ketangkasan atau ketrampilan dari apa yang telah dipelajari [9]. Tujuan penggunaan metode drill, siswa diharapkan dapat: 1) memiliki ketrampilan memoris atau gerak, 2) mengembangkan kecakapan intelek, 3) memiliki kemampuan menghubungkan antara suatu keadaan, 4) dapat menggunakan daya pikirnya yang makin lama makin bertambah baik, dan 5) pengetahuan peserta didik akan 
bertambah dari berbagai segi dan peserta didik akan memperoleh pemahaman yang lebih baik dan mendalaM [1]. Penerapan metode drill pada proses pembelajaran matematika pada materi integral dapat meningkatkan hasil belajar matematika [13]. Metode pembelajaran Drill dapat meningkatkan kemampuan pemecahan masalah matematis siswa [4].

Metode pemberian tugas adalah suatu cara penyajian pelajaran dengan cara guru memberikan tugas tertentu kepada siswa dalam yang telah ditentukan dan kemudian siswa mempertanggungjawabkan tugas yang dibebankan kepadanya [12]. Pemberian tugas atau soal-soal kepada siswa dapat diberikan baik di dalam kelas pada saat proses pembelajaran ataupun sebagai pekerjaan rumah. Tujuan pengggunaan metode pemberian tugas untuk 1) latihan dan ketrampilan, serta untuk menambah kecepatan belajar dan keakuratan belajar, 2) membaca, meresapkan, dan meringkas apa yang dipelajari, 3) mendorong siswa untuk bertanggung jawab terhadap pelajaran, dan 4) mengembangkan belajar mandiri [3]. Metode pemberian tugas dapat meningkatkan hasil belajar matematika [11].

Pemecahan masalah pada penelitian ini merujuk pada polya (1973) yaitu 1) Understanding the problem (memahami masalah), 2) Devising a plan (merencanakan penyelesaian), 3) Carrying out the plan (menyelesaikan masalah sesuai rencana), 4) Looking back (memeriksa kembali). Pada penelitian ini, langkah pemecahan masalah yang digunakan hanya pada tahap 1 dan 2 yaitu memahami masalah dan merencanakan penyelesaian. Memahami masalah dan merencanakan penyelesaian kalau dikaitkan dalam prosedure uji hipoesis itu seperti langkah 1 sampai 3 yaitu 1) rumuskan
$\mathrm{H}_{0}$ dan $\mathrm{H}_{\mathrm{a}}, 2$ ) tentukan taraf signifikansi, dan 3) pilihlah statistik uji yang cocok untuk menguji hipotesis yang telah dirumuskan.

\section{METODE PENELITIAN}

Penelitian ini termasuk penelitian eksperimental semu dengan one group pretest-posttest design. Populasi pada penelitian ini adalah semua mahasiswa PGSD yang mengikuti matakuliah statistika pendidikan pada tahun ajaran 2019/2020. Teknik pengambilan sampel pada penelitian ini menggunakan simple random sampling. Penelitian dilakukan kepada 30 mahasiswa PGSD yang mengikuti matakuliah statistika pendidikan yang diambil secara acak.

Penelitian di awali dengan pemberian soal pretest kepada mahasiswa. pemberian soal pretest tersebut digunakan untuk mengetahui kemampuan pemecahan masalah awal mahasiswa sebelum diberikan perlakuan strategi drill dan tugas. Penelitian selanjutnya memberikan perlakuan pembelajaran dengan menggunakan strategi drill dan tugas selama dua hari. Terakhir yaitu memberikan soal posttest yang mana bertujuan untuk mengetahui kemampuan pemecahan masalah setelah diberikan perlakuan pembelajaran dengan menggunakan strategi drill dan tugas.

Dalam penelitian ini ada variabel bebas dan variabel terikat. Variabel bebas pada penelitian ini yaitu strategi drill dan tugas. Variabel terikat pada penelitian ini adalah kemampuan pemecahan masalah.Teknik pengumpulan data dilakukan dengan menggunakan metode tes. Metode tes digunakan untuk mengumpulkan data kemampuan pemecahan masalah. Instrumen yang digunakan untuk tes kemampuan pemecahan masalah adalah 3 butir soal tes uraian. Analisis 
data pada penelitian menggunakan uji $\mathrm{T}$ berpasangan dengan uji prasyaratnya yaitu uji normalitas.

\section{HASIL DAN PEMBAHASAN}

Penelitian ini merupakan penelitian untuk mencari ada atau tidaknya peningkatan kemampuan pemecahan masalah mahasiswa. Hasil penelitian menggunakan uji $\mathrm{T}$ berpasangan yang mana uji prasayarat dari uji $T$ berpasangan adalah uji normalitas. Hasil Uji normalitas menggunakan SPSS disajikan dalam Tabel 1 berikut:

Tabel 1. Tests of Normality

\begin{tabular}{lccccccc}
\hline & \multicolumn{3}{c}{ Kolmogorov-Smirnova } & \multicolumn{4}{c}{ Shapiro-Wilk } \\
\cline { 2 - 8 } & Statistic & Df & Sig. & Statistic & Df & Sig. \\
\hline Pretest & 0,153 & 30 & 0,072 & 0,965 & 30 & 0,422 \\
\hline Posttest & 0,098 & 30 & $0,200^{*}$ & 0,962 & 30 & 0,348 \\
\hline a. Lilliefors Significance Correction \\
*. This is a lower bound of the true significance.
\end{tabular}

Berdasarkan Tabel 1, pada data pretest berdasarkan uji kolmogrovsmirnov $(0,72>0,05)$ dan uji Shapirowilk $(0,422>0,05)$, hal ini dapat disimpulkan bahwa data pretest berdistribusi Normal. Dan pada data posttest berdasarkan uji kolmogrovsmirnov $(0,200>0,05)$ dan uji Shapirowilk $(0,348>0,05)$, hal ini dapat disimpulkan bahwa data posttest berdistribusi normal. Karena semua data berdistribusi normal, kemudian dilanjut dengan uji hipotesis yaitu menggunakan uji $\mathrm{T}$ berpasangan. Hasil uji $\mathrm{T}$ berpasangan dengan menggunakan SPSS disajikan dalam tabel 2 berikut:

Tabel 2. Paired Samples Test

\begin{tabular}{ccccc}
\hline & & & \multicolumn{2}{c}{$\begin{array}{c}\text { Sig. (2- } \\
\text { tailed) }\end{array}$} \\
\hline Pair 1 & Pretest & & & \\
& - \\
& Posttest & $-5,656$ & 29 & 0,000 \\
\hline
\end{tabular}

Berdasarkan Tabel 2, diperoleh bahwa nilai sig. (2tailed) $(0,000<0,05)$ ini menunjukan bahwa $\mathrm{H}_{0}$ ditolak. Hal ini berarti terdapat peningkatan kemampuan pemecahan masalah mahasiswa dari sebelum diberikan perlakuan pembelajaran menggunakan strategi drill dan tugas dengan setelah diberikan perlakuan pembelajaran menggunakan strategi drill dan tugas. Peningkatan kemampuan pemecahan masalah mahasiswa dapat dilihat di tabel 3 berikut:

Tabel 3. Paired Samples Statistics

\begin{tabular}{|c|c|c|c|c|c|}
\hline & & Mean & $\mathrm{N}$ & $\begin{array}{c}\text { Std. } \\
\text { Deviation }\end{array}$ & $\begin{array}{l}\text { Std. Error } \\
\text { Mean }\end{array}$ \\
\hline \multirow{2}{*}{ Pair 1} & Pretest & 52.3333 & 30 & 17.59376 & 3.21217 \\
\hline & Posttest & 64.2333 & 30 & 17.46856 & 3.18931 \\
\hline
\end{tabular}

Berdasarkan Tabel 3, diperoleh bahwa nilai rerata mahasiswa sebelum diberikan perlakuan pembelajaran menggunakan strategi drill dan tugas sebesar 52,333 dan nilai rerata mahasiswa setelah diberikan perlakuan pembelajaran dengan menggunakan strategi strategi drill dan tugas sebesar 64,233 . Hal ini berarti ada peningkatan sebesar 11,9.

Adanya peningkatan kemampuan pemecahan masalah mahasiswa dikarenakan banyaknya latihan soal yang diberikan dalam proses pembelajaran untuk lebih memahami materi yang sedang dipelajarin oleh mahasiswa. Materi pembelajaran pada penelitian ini yaitu uji hipotesis, yang mana uji hipotesis membahas tentang uji $\mathrm{T}$ satu sampel (one sample $t$ test), uji $\mathrm{t}$ untuk dua sampel bebas atau independen (independent sample test) dan uji $\mathrm{T}$ berpasangan (paired sample $t$ test).

Pada hari pertama pembelajaran, mahasiswa diawali dengan mempelajari mempelajari materi hipotesis nol dan hipotesis alternatif, prosedure uji hipotesi dan uji T satu

sampel (one sample $t$ test). Pembelajaran di awali dengan menjelaskan hipotesis 
nol dan hipotesis alternatif, dan menjelaskan prosedure uji hipotesis. Pembelajaran semangkin menarik ketika membahas tentang contoh soal pada uji $\mathrm{T}$ satu sampel. Contoh soal pertama sebagai berikut:

Menurut pengalaman selama beberapa tahun terakhir ini, pada ujian matematika standar yang diberikan kepada siswa-siswa SMU di Surakarta diperoleh rerata 74.5 dengan deviasi baku 8.0. Tahun ini dilaksanakan metode baru untuk dapat meningkatkan kemampuan siswa dalam bidang studi matematika tersebut. Setelah metode baru tersebut dilaksanakan, secara random dari populasinya, diambil 200 siswa untuk dites dengan ujian matematika standar dan tenyata dari 200 siswa tersebut diperoleh rataan 75.9. Jika diambil $\alpha=5 \%$, apakah dapat disimpulkan bahwa metode baru tersebut dapat meningkatkan kemampuan siswa dalam matematika?

Pada pembahasan contoh soal pertama, mahasiswa masih kebingunan dalam memahami masalah dan merencanakan penyelesaian. Kebingungan memahami masalah mahasiswa terlihat ketika mereka megidentifikasi soal. Misalnya dari rerata 74,5 dan 75,9. Antara rerata tersebut, mahasiswa kebingungan untuk menentukan mana rerata miliknya populasi ataukah rerata miliknya sampel yang mana nantinya akan berdampak pada simbol yang digunakan antara menggunakan $\mu$ atau menggunakan $\bar{X}$. Sama halnya dengan rerata, pada deviasi baku mahasiswa juga mengalami kebingungan yang sama. Kebingunan mahasiswa pada merencanakan penyelesaian juga terlihat ketika mahasiswa diminta untuk merumuskan hipotesis nol dan hipotesis alternatif. Mahasiswa masih kebingungan menggunakan tipe hipotesis yang tepat dan sesuai dengan pertanyaan dari soal tersebut. Pada merencanakan penyelesaian dalam menentukan statistik uji yang digunakan, mahasiswa masih kebingunan dalam menentukan statistik uji yang digunakan. Mereka tidak memperhatika prasyarat dari statistik uji yang digunakan.

Pada contoh soal kedua, sebagian mahasiswa sudah bisa memahami masalah pada soal, mahasiswa sudah bisa tentang apa yang diketaui dan apa yang ditanyakan. pada tahap merencanakan, mahasiswa masih mengalami permasalahan yang sama dalam menyusun atau merumuskan hipotesis nol dan hipotesis alternatif. Kebingungan mahasiswa pada soal kedua membuat pembelajaran lebih menarik, karena berdasarkan pada contoh soal pertama, sebagian mahasiswa berani memberikan pendapatnya dalam perumusan hipotesis nol dan hipotesis alternatif walaupun perumusan hipotesis nol dan hipotesis alternatif tidak tepat. Pada merencanakan penyelesaian dalam menentukan statistik uji yang digunakan, sebagian besar mahasiswa dapat menentukan statistik uji yang digunakan.

Pada contoh soal ketiga, mahasiswa sudah bisa memahami masalah pada soal, mahasiswa sudah bisa tentang apa yang diketaui dan apa yang ditanyakan. pada tahap merencanakan, sebagian mahasiswa masih mengalami permasalahan yang sama dalam menyusun atau merumuskan hipotesis nol dan hipotesis alternatif. Pada contoh soal ketiga, ada sebagian mahasiswa yang sudah benar dalam merumuskan hipotesis nol dan hipotesis alternatif. Pada merencanakan penyelesaian dalam menentukan statistik uji yang 
digunakan, sebagian besar mahasiswa dapat menentukan statistik uji yang digunakan.

Pada hari kedua pembelajaran, mahasiswa mempelajari tentang uji $t$ untuk dua sampel bebas atau independen (independent sample test) dan uji $\mathrm{T}$ berpasangan (paired sample $t$ test). Pada pembahasan soal pertama, sebagian mahasiswa sudah dapat memahami masalah yang ada, ada sebagian mahasiswa yang masih kebingungan hal ini karena pada pertemuan pertama baru membahas pada satu sampel, sedangkan pada contoh ini ada dua sampel. Pada merencanakan penyelesaian tentang hipotesis, sebagian mahasiswa masih ada yang salah dalam merumuskan hipotesis nol dan hipotesis alternatif. Mahasiswa merumuskan hipotesis menggunakan hipotesis untuk satu sampel. Sebagian mahasiswa yang lain masih salah dalam memilih tipe hipotesis yang tepat sesuai dengan pertanyaan soal. Akan tetapi, ada juga mahasiswa yang sudah bisa merumuskan hipotesis nol dan hipotesis alternatif dengan tepat. Pada merencanakan penyelesaian dalam menentukan statistik uji yang digunakan, sebagian mahasiswa masih salah dalam menentukan statistik uji yang digunakan. Mereka tidak memperhatika prasyarat dari statistik uji yang digunakan.

Pada contoh soal kedua, mahasiswa sudah bisa memahami masalah dengan baik. Mahasiswa sudah tidak lagi merumuskan hipotesis nol dan hipotesis alternative menggunakan hipotesis satu sampel. Akan tetapi, sebagian mahasiswa juga masih ada yang salah dalam merumuskan hipotesis nol dan hipotesis alternatif khusunya dalam menentukan tipe hipotesis yang digunakan yang sesuai dengan pertanyaan soal. Pada merencanakan penyelesaian dalam menentukan statistik uji yang digunakan, sebagian besar mahasiswa dapat menentukan statistik uji yang digunakan.

Pada contoh soal ketiga, mahasiswa sudah bisa memahami masalah dengan baik. Sebagian besar mahasiswa sudah dapat merumuskan hipotesis nol dan hipotesis alternative. Akan tetapi pada merencanakan penyelesaian dalam statistik uji yang digunakan, mahasiswa salah dalam memilih statistik uji yang digunakan. Mahasiwa tidak memperhatikan bahwa soal ketiga merupakan soal yang saling berkaitan. Sehingga seharusnya menggunakan statistik uji $t$ berpasangan. Statistik uji yang digunakan mahasiswa adalah statistika uji t independen.

Pada contoh soal ke empat dan contoh soal kelima, pembelajaran berjalan dengan baik. Sebagian besar mahasiswa sudah bisa memahami masalah, merumuskan hipotesis nol dan hipotesis alternative dan sudah bisa menentukan statistik uji yang digunakan.

Pembelajaran menggunakan strategi drill dan tugas membuat mahasiswa lebih aktif dalam pembelajaran. Keaktifan mahasiswa terlihat ketika proses pembelajaran terjadi adanya proses tanya jawab baik itu antara mahasiswa dengan mahasiswa ataupun antara mahasiswa dengan dosen. Pembelajaran menggunakan strategi drill dan tugas membuat mahasiswa menjadi lebih kritis dalam berpikir. Pembelajaran menggunakan strategi drill dan tugas membuat diskusi antara mahasiswa dan dosen menjadi lebih menyenangkan. strategi drill dan tugas menjadikan mahasiswa menjadi mahasiswa yang mandiri. strategi drill dan tugas menjadikan pula mahasiswa yang bertanggung jawab. Akan tetapi, pembelajaran menggunakan strategi drill dan tugas memerlukan waktu yang 
lebih bagi mahasiswa untuk mengerjakan soal baik dalam kelas ataupun diluar kelas.

Hasil penelitian ini adalah terdapat peningkatan kemampuan pemecahan masalah mahasiswa dari sebelum diberikan perlakuan pembelajaran menggunakan strategi drill dan tugas dengan setelah diberikan perlakuan pembelajaran menggunakan strategi drill dan tugas. Hasil penelitian ini hampir serupa dengan penelitian dari [13], [3], [4].

\section{KESIMPULAN}

Berdasarkan hasil penelitian disimpulkan bahwa terdapat peningkatan kemampuan pemecahan masalah mahasiswa dari sebelum diberikan perlakuan pembelajaran menggunakan strategi pemberian tugas, drill dan latihan dengan setelah diberikan perlakuan pembelajaran menggunakan strategi pemberian tugas, drill dan latihan. Terdapat peningkatan rerata kemampuan pemecahan masalah sebesar 11,9 yang mana rerata sebelum diberi perlakuan sebesar 52,333 dan rerata setelah diberi perlakuan sebesar 64,233 .

Berdasarkan kesimpulan di atas, penulis dapat memberikan saran bahwa sebagai pendidik matematika, ada baiknya mahasiswa ataupun siswa untuk lebih sering diberikan soal-soal latihan dalam proses pembelajaran ataupun sebagai pekerjaan rumah.

\section{DAFTAR PUSTAKA}

[1] Armai, Arief. (2002). Pengantar Ilmu dan Metodologi Pendidikan Islam. Jakarta: Intermasa

[2] Budiyono. (2013). Statistika Untuk Penelitian. Surakarta: UNS Press

[3] Kasmadi, Hartono. (1991). Teknik Mengajar. Semarang: IKIP Semarang Press
[4] Kusumawati, Elli dan Irwanto, Randi Ahmad. (2016). Penerapan metode pembelajaran Drill untuk meningkatkan kemampuan pemecahan masalah matematis siswa kelas VII SMP. Jurnal pendikan matematika Vol. 4 No. 1

[4] Nurjana. (2015). Penggunaan Metode Pemberian Tugas Untuk Meningkatkan Keterampilan Menulis Surat Siswa Kelas IV SDN 2 Lais. Jurnal Kreatif Tadulako Online Vol. 4 No. 8 ISSN 2354-614X

[5] Polya, G. (1973). How To Solve It. New Jersey: Princeton University Press

[6] Ramayulis. (2010). Metodologi Pendidikan Agama Islam. Jakarta: kalam mulia

[7] Roestiyah, N.K. (1985). Strategi Belajar Mengajar. Jakarta: Bina Aksara

[8] Siswono, Tatag yuli Eko. (2018). Pembelajaran Matematika Berbasis Pengajuan Dan Pemecahan Masalah. Bandung: PT Remaja Rosdakarya

[9] Sudjana, Nana. (1995). Dasar-Dasar Proses Belajar Mengajar. Bandung: Sinar Baru Algensindo

[10] Sumarmo, U dan Hendriana, $H$. (2014). Penilaian Pembelajaran Matematika. Bandung: Refika Aditama

[11] Sutriani, dkk. (2016). Penerapan Metode Pemberian Tugas untuk Meningkatkan Hasil Belajar Pada Materi Penjumlahan Dan Pengurangan Pecahan di Kelas V SDN 2 Bukit Harapan. Jurnal Kreatif Tadulako Online Vol. 4 No. 1 ISSN 2354-614X

[12] Usman, Muh. Uzer dan Setiawati, Lilis. (1993). Upaya optimalisasi kegiatan Belajar mengajar. Bandung: Rosyda Karya

[13] Wahyuni, Nida. (2016). Penggunaan Metode Drill Dalam Pembelajaran Matematika. 
Jurnal THEOREMS (The Original Research of Mathematics) Vol. 5 No. 2, Januari 2021. hal. 221-228

URL: http://jurnal.unma.ac.id/index.php/th

Naskah masuk: 24-12-2020 Naskah diperbaiki: 04-01-2021 Naskah diterima: 05-01-2021

Prosiding Seminar Nasional di Universitas Cokroaminoto Palopo tahun 2016 Vol. 02, No. 1 ISSN 24431109 